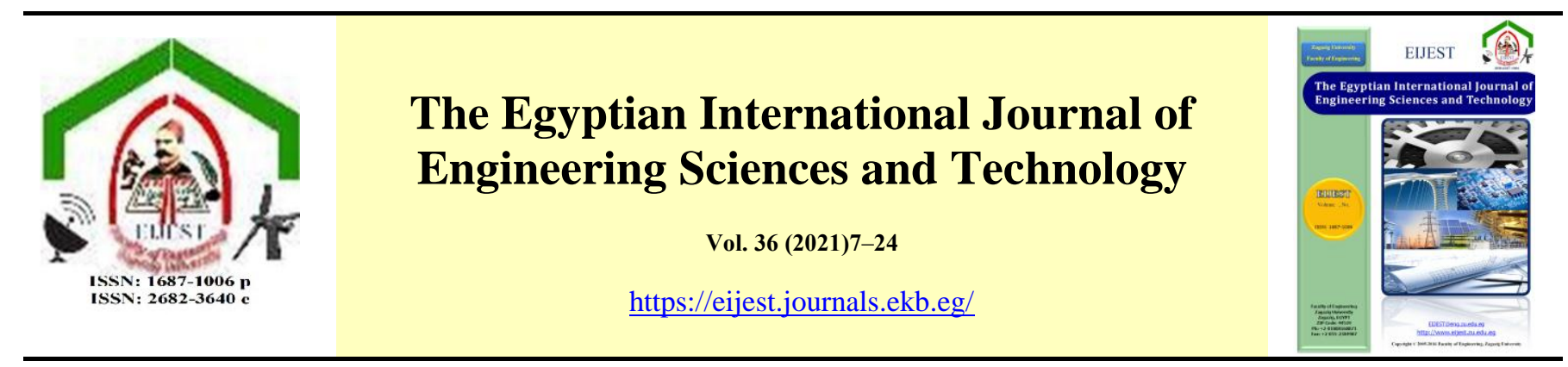

\title{
Investigation of the potentials and constrains of employing robots in construction in Egypt
}

\author{
Ghareeb M. Ismail $^{\mathrm{a}^{*}}$, Hussein M. El-shanwany ${ }^{\mathrm{b}}$, Zeyad T. El-sayad ${ }^{\mathrm{c}}$ \\ ${ }^{a}$ Demonstrator at Architectural engineering dep., Faculty of engineering, Zagazig university, Egypt. \\ ${ }^{b}$ Professor of architecture and building technology, Faculty of engineering, Zagazig university, Egypt. \\ ${ }^{c}$ Assistant Professor, Faculty of engineering, Alexandria university, Egypt \\ A R T I C L E I N F O

\section{A B S T R A C T}

Keywords:

EGYPT Construction

Construction Robots

Automation technology

3D Concrete Printing

This paper aims to investigate the potentials and constraints of employing robots in construction in Egypt, In order to treat the shortage of current technologies. Egypt suffers from many issues in the construction sector, such as lack of skilled labour, poor quality, and productivity. Those issues lead to increase project time, total costs, amount of waste in materials, and rate of accidents. Current development projects cannot be achieved with the previous issues and use of traditional technology. Therefore, the automation technologies in construction have to be examined to determine the advantages and disadvantages of their application and the ability of robotics technology in the construction sector in Egypt to achieve the development projects. Its advantages are summarized in saving time, reducing cost, increasing productivity, quality, and working in different environmental conditions. Capital cost is one of the disadvantages of that technology. a SWOT i.e. (the strengths, weaknesses, opportunities, and threats) analysis had been used, the analysis indicates that the application of this technology will increase productivity, at lower cost, higher quality, and accuracy. in addition to preserving lives and materials. Some challenges revolving around the capital cost of technology and the future of employment.

\section{Introduction}

The construction industry's contribution to the GDP in industrialized countries is about 7-10\%[1]. Construction sector represents about $6.3 \%$ from GDP in Egypt as of 2019/2020 [2].

The construction sector in Egypt is suffering from some issues such as the following:

- Labour Productivity was affected undisciplined labour, labour expensive and on-site accident. [3].

- Construction Quality, the construction industry in Egypt is still characterized by poor quality [4][5].

- Delay in construction projects refer to Shortage in labour; Unskilled operators; Poor equipment productivity; Weather conditions ; Accidents during construction and Force Majeure as Epidemics [6][7].

- High cost of construction is resulted by many factors such as high cost of skilled labour; errors during construction; costs due to unskilled labour; Waste of material usage ;Location of project; not optimized construction methods and Improper supervision [8].

The coronavirus (COVID-19) disease, known to the whole world as a global pandemic, one of the most dangerous disasters affecting countries' economic sectors. In Egypt, The construction sector has slowed, particularly at the outset of the pandemic, and reports suggest that the sector's growth over the next few years will be weaker than previously anticipated[9].

All these issues are opening new horizons to search for more automated construction technologies including robots, which are used recently to avoid the shortage of quality and productivity and wasting of material, costs, and accident rates.

The first applications of robotic technologies to the construction industry were appeared in Japan during the 70's, in order to improve the quality of prefabricated elements for modular residential buildings. Since then, robots have been started spreading in the construction industry, slowly moving from factories to actual construction sites [10]. A number of new companies are seeking to exploit the opportunity of that technologies.

* Corresponding author. Tel.: 0201092152223

E-mail address: eng_ghareeb25@yahoo.com 
Some have planned to examine the Possibilities of novel techniques such as 3D concrete printing, while others are automating existing construction operations such as bricklaying. In addition to various operations that require high power and high accuracy [11].

\section{Research Objectives}

This paper focuses on investigating the existing and future potential of employing robots in the construction industry, in addition to the opportunities and challenges facing their application in Egypt.

\section{Research Limitations}

- Many of the examples presented are not available in Egypt for a practical study to prove the results.

- Some of these examples are still emerging and under research, the information available about them is scarce.

- The data produced by companies is the result of specific conditions and environments. It may be advertising data.

- There are differences in labor cost and availability between technology exporting countries and Egypt.

\section{Research Methodology}

The research methodology is based on an inductive approach through review opportunities and challenges of employing robots in construction and comparative approach through Comparing case studies advantages and disadvantages.

The research focuses on some case studies for three main robot's category Aerial Robots, terrestrial robots, and Underwater robots. Criteria of choosing case studies depend on available data and technologies that are actually applied or under empirical study - not a theoretical study for application.

Case studies were analyzed individually by SWOT analysis tool to determine the strength, weakness, opportunities, and threats for applying this technology in Egypt.

\section{Robots}

\subsection{Definition}

The Oxford English Dictionary gives the following definition: "A machine capable of carrying out a complex series of actions automatically, especially one programmable by a computer."

A vital element of robots that is not mentioned explicitly in the definition is the use of sensors. Most automata do not have sensors and cannot adapt their actions to their environment. Sensors are what enable a robot to carry out Sans complex tasks [12].

Another definition, A robot is an actuated mechanism programmable in two or more axes with a degree of autonomy, moving within its environment, to perform intended tasks. Autonomy in this context means the ability to perform intended tasks based on current state and sensing, without human intervention. [13].

\subsection{Classification of Robots Types}

Robots can be classified according to their mobility; they can be classified into fixed (stationary) and mobile robots Fig. 1. These two types of robots have very different working environments. Fixed (stationary) robots are mostly industrial robots that work in concentrated environments to produce repetitive tasks. Mobile robots can be divided into three types according to the environment in which they move and the mechanism of mobility: aerial, terrestrial, and aquatic [14].

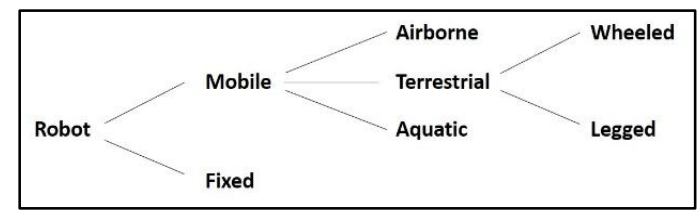

Fig. 1. Classification of robots according to mobility and work environment [14].

According to the previous classification and ROBOTPARK classification which classified robots by locomotion systems[15]. In addition to a survey and prototypes overview which had been done by a group of researchers about recent developments in Aerial Robotics [16]. These types had been summarized in the following Fig. 2 .

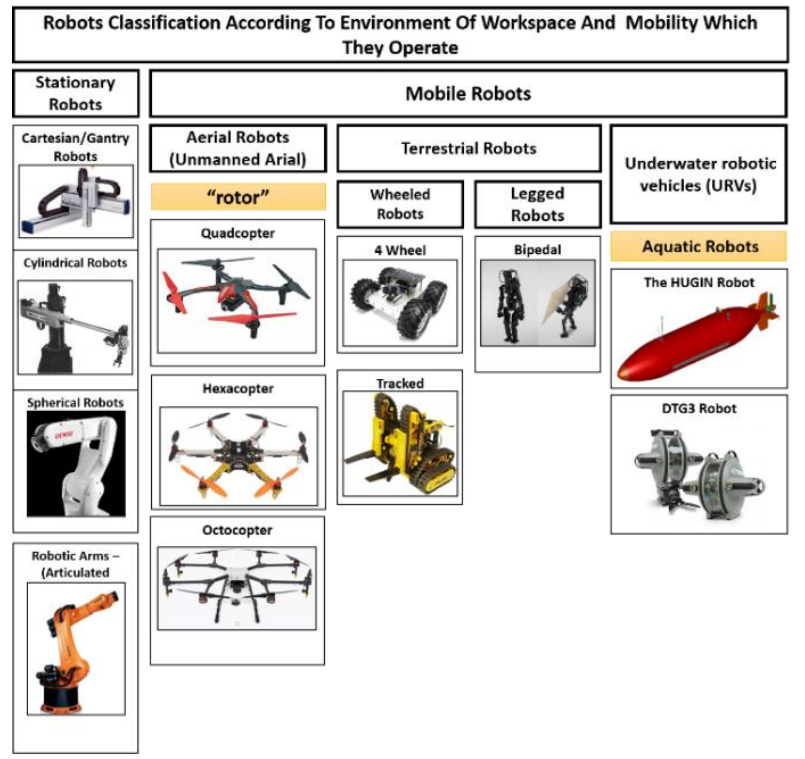

Fig. 2. Robots' classification according to their environment of workspace and mobility[15]. Note: The figure has been modified by the author. 


\subsubsection{Unmanned Aerial Robot (Drones)}

Drones or unmanned aerial robots are playing an increasingly important role in trades (construction/plumbing) By $11.5 \%$ in the sectors of using drones in the UK, and their use has soared in recent years. According to a survey carried out by dronesdirect.co.uk, one of the leading drone retailers, 12 percent of construction firms in the UK are now using the technology[17].

one of the key areas where drones and UAVs can improve performance and save time in construction, activities is planning and monitoring. In the construction industry, the technology can be applied on a much larger scale. For example, drones and UAVs can be potentially used at several stages in a construction project including preplanning, detailed survey and mapping of the job site, construction process monitoring, post-build checks, and sales and marketing [18].

\subsubsection{Boomerang a smart drone aerial mapping system}

Identified Technologies is a USA company founded in 2013, develop a smart drone aerial mapping system called Boomerang Fig. 3, which used in commercial construction sites for continuous tracking and monitoring. The drone is developed to be a safer, cheaper, faster, and more accurate method for surveying and mapping active projects compared to alternative methods relying on aerial survey and manned survey teams.

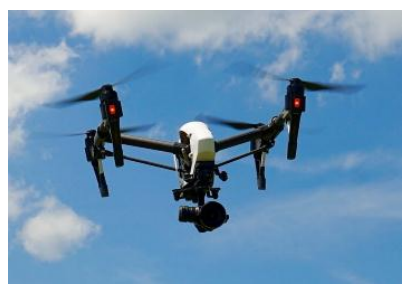

Fig. 3. Boomerang a smart drone aerial mapping system[19].

According to Identified Technologies, a provider of commercial drone survey services, the lead time estimated of a traditional aerial survey of a 100-acre site by helicopter is about 12 weeks, which includes a four-week booking lead time, two- hours data gathering, and eight-week data processing. For the same site area, A manned survey team, the lead time is about 7 weeks, which includes a one-week booking lead time, four-week data gathering, and two-week weeks data processing. A commercial drone service can gather the necessary data in about $9 \mathrm{~min}$ and provides the whole service in 6 h Fig. 4 [20].

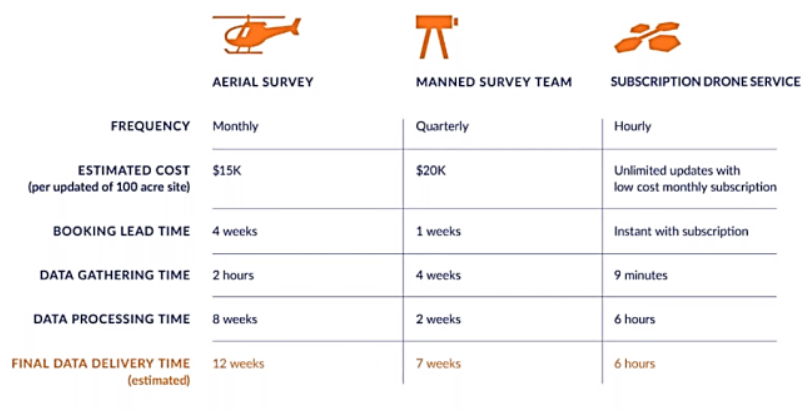

Fig. 4. Simulated Comparison between Drone survey service and other alternatives [20].

\subsubsection{Drones Used in Placing Pilot Lines of Suspension Bridges}

In the construction process of suspension bridges cables, before the catwalk is constructed, a pilot line must be placed first from one anchorage across the tower to another anchorage to form the cables. Helicopters or boats are common ways have been used to position the pilot line. However, these ways have some constrain. Boats are not used in mountain areas, and helicopters are riskier due to the local weather or landscape restrictions. In addition to, This ways need to licensed professional operators and could be time-consuming and costly [22]. Drones have ability to place pilot lines in suspension bridges. These drones have been used in some newly built suspension bridges and have been proved to be practical.

China has used drones in many suspension bridges. Longjiang Suspension Bridge, a mega bridge is being built in southwest China. The 2,009 - meter-long bridge sits over a river valley with a main span 1200 meters. Engineers use a drone to help install cables; It carry a 2000 meter long cable to fly from one end of the valley to the other and connect to the main towers Fig.5 [23].

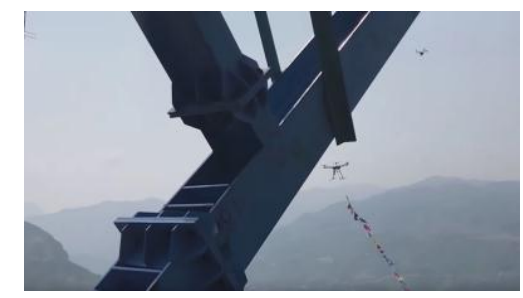

Fig. 5 The drone carrying a cable between the bridge's two towers [23].

In 2017, Chinese workers used a drone to lay cables during construction Xingkang Bridge over raging river with a 1200 -meter span Fig.6. The drones were not used to install all of the cables on the bridge. the drone sends the small rope to the opposite shore, the staff then uses the small rope to pull the big rope and finally the steel rope is pulled across the river to set up a traction system. According to Sichuan Daily, drone is 100 times more efficient than the 
traditional method, which is to use a boat, a manned helicopter or a mini rocket [24].

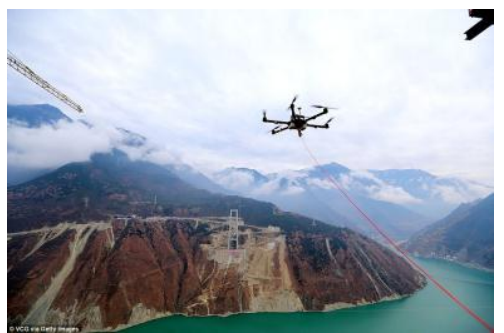

Fig. 6 The six-rotor drone flies across the river[24].

According to previous three case studies, advantages and disadvantages of using drones in construction sector can be summarized into the following.

Advantages:

- Using in large sites.

- Multi-tasking.

- Be a safer, cheaper, faster, and more accurate method for surveying and mapping.

- Capture various data.

- Using to aid planning, design, construction and maintenance.

- Moving long distances.

Disadvantages:

- Limitation is the payload problem.

- More affected by weather factors.

- A distraction source for the employment on the site.

- Limitation of flying time; some missions may not be done with one time flying.

- Need professional trainings.

\subsubsection{Monitoring of Construction Project using Drones}

According to a study, it was applied to a case study construction project of a single-story residential apartments building. Drones are used to monitor construction activities continuously. A drone captures various data four times with different height and camera angle settings, to ensure all angles are photographed [21].

After the process of aerial photography, using 3DF Zephyr software to generate a $3 \mathrm{D}$ reconstruction model by the collected capture data. The $3 \mathrm{D}$ model is then imported into REVIT and overlaid with the actual REVIT building models to compare different dimensions of the buildings. By using 3d model generated, we can compare volume between construction plan/schedule and on-site progress for the selected case study project. The comparison between the BIM model (red colour) and drone model (green colour) shows differences and progress according to the schedule Fig. 7.

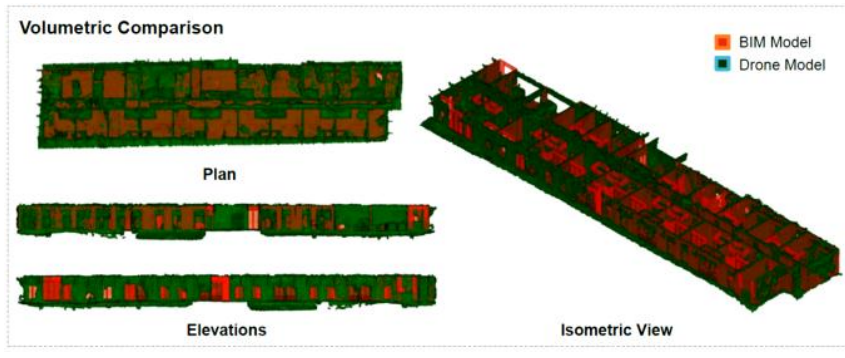

Fig. 7. The volumetric comparison between construction plan/schedule and on-site progress[21].

We can also monitor other comparisons for project elements such as toilets and windows. According to case study, all toilets are on schedule and the placement of windows is delayed by schedule Fig. 8 .
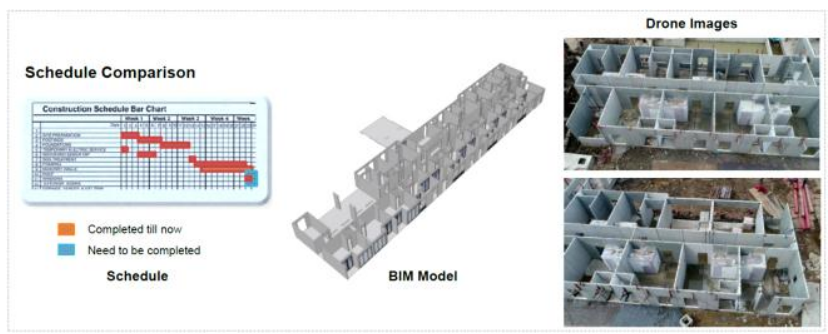

Fig. 8. The placement of windows is delayed by schedule[21].

\subsubsection{Terrestrial Robots (Ground Robots)}

\subsubsection{Husquarna DXR Demolition Robot}

Husqvarna provides construction professionals with support, service and a wide range of machines in demolition field.

Husqvarna Construction Products' demolition robots are More innovative, easy to operate, easy to maintenance, have a sturdy design and responsive controls and deliver precise demolition power[25]. The company has issued many of robot's versions; DXR 310, DXR 300, DXR 270, DXR 250 and DXR 140. Each of these versions has its advantages, and we will review DXR 310 applications and benefits.

The DXR 310 is the most powerful remote-controlled demolition robot with a telescopic arm that can extend over 5 meters. it delivers a power of $22 \mathrm{~kW}$, making it more efficient in tough environments, and bright LED lights provide good workplace illumination. The robot is also narrower than $80 \mathrm{~cm}$, so it can fit through room doors Fig. 9 [26][27]. 


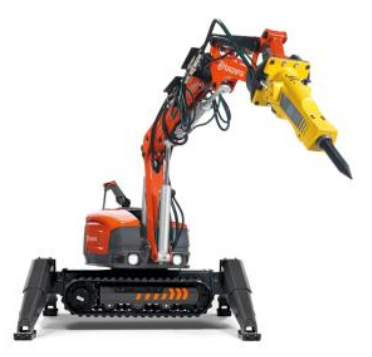

Fig.9. Husqvarna DXR 310 [26].

Husqvarna DXR 310 Applications[28]:

- Perfect for demolition and smaller excavation work, both indoors and out.

- Efficient in tough environments, like industry.

- Handles building demolition in most types of materials.

- Ideal for demolition of concrete and brick constructions.

Husqvarna DXR 310 Benefits[26]:

- Telescopic arm is high-precision and extendable for long reach and easy positioning of the tool.

- The robot has Compact design and low weight gives access to narrow spaces.

- It can pass through an opening $78 \mathrm{~cm}$ wide.

- It can determine the position of the tool smoothly and precision combined with the software.

- The robot can be controlled with Bluetooth remote control, making it easier to read and control all parameters quickly.

- Safer operation, it is followed up from a distance.

- Extremely robust and durable.

The robot can be equipped with a number of different demonstrate tools, including[25]:

- Breaker, standard

- Breaker, heat protective kit (two options to choose from)

- Crusher

- Steel Shearer

- Grapple

- Bucket, narrow, standard or wide

The robot has some disadvantages; it should be left to professional's operators with experience to avoid damage more than needed. DXR 310 costs 220,319.88 USD. Cost might be a hindrance, Despite its efficiency. There are accessibility concerns, although the small size and motorized tracks can navigate many different terrain types[29].

According to a questionnaire conducted on a group of contractors about drawbacks of demolition robots, it's found that initial costs, repair costs, price of repair and training operators the most common drawbacks of using this robots[30].

\subsubsection{Mobile Robotic Brickwork}

Construction Robotics is a New York based company founded in 2007. They have designed and engineered SAM, short for Semi-automated Mason launched in 2014, is a brick laying robot. SAM100 is the first commercially available bricklaying robot for onsite masonry construction, which it formally launched in 2014 Fig. 10 [11].

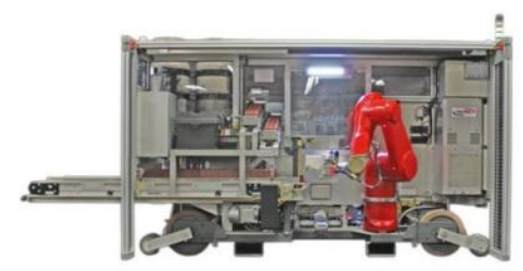

Fig. 10. The SAM100 bricklaying robot[11].

The SAM100 is priced at about $\$ 500,000$ and can lay around 2,000 -3,000 bricks per day using its combination of a conveyor belt, a robotic arm and gripper and a concrete pump. While, Human builder produce average around 400500 bricks per day. By the laser and suite of sensors had been equipped in the robot, it allows to measure critical operational variables including orientation, angles, depths and distance[31].

Many of construction companies are utilizing this technology. An Indiana-based construction company increased bricklaying productivity by 400 percent when it has engaged the SAM100 into its construction projects. At Willhelm Construction in Indianapolis, Mason's productivity increased from lay 400 modular bricks a day to lay more than 2,000 bricks a day, after purchasing the SAM100. Its record is over 3,000[31].

According to an analysis study to use the SAM 100 in a project, the robot can complete tasks at a rate that is five to six times faster than a masonry crew. With four to five laborers to assist the machine and operate it, Sam could accomplish a standard project that would require a crew of 15-20 masons to complete the masonry work. The SAM100 only requires four to five laborers to assist the machine and operate it[31].

There are some drawbacks from using the SAM 100. It requires amount of time to set up. The SAM100 needs to be perfectly leveled on the platform, the tracks on the robot must be aligned to the wall, it has to be anchored and the lasers must be accurately set up. Robot raise to up level with vertical platform Fig.11[31][32].

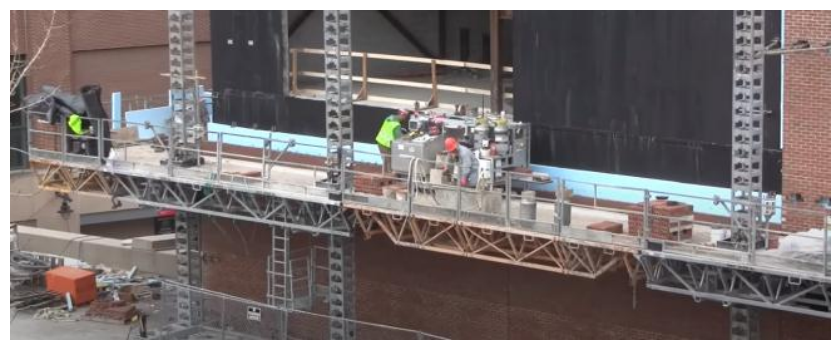

Fig.11. The SAM 100 work on vertical platform[32] . 
SAM100 does not fully automate the bricklaying process. The robot picks up the bricks, applies the mortar and positions the bricks on the wall but still requires a human to work alongside to smooth over the mortar before it places further bricks Fig.12 [31][32].

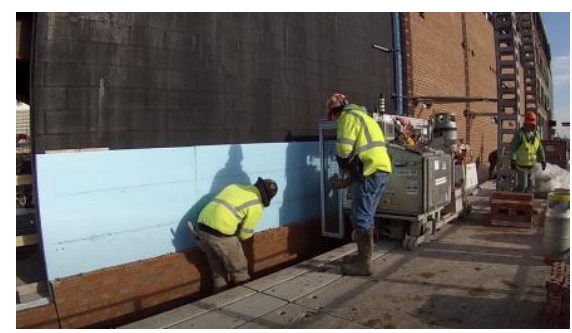

Fig.12. The SAM 100 requires human workers to finish the work [32] .

SAM100 is more effective on projects include large boxshape structures, such as warehouses. In addition to projects including elevations of the walls has high 10-15 meter and long around 30 meters. The robot may be not suitable to the small project[31].

\subsubsection{3D Printing Concrete}

In 1984, the first 3D printer was invented by Charles $\mathrm{W}$ and 3D printing technology has become one of the fastest growing technologies over the last decades. At the beginning it was very complicated and expensive technology. Over the years, 3D printing started to be present in everyday life and printers became commonly used in all kinds of industry fields. 3D printing can also be referred to as 'additive manufacturing,' especially when referring to its use within a manufacturing. Now, technology has a lot of achievements, have been made in medicine, automotive or aerospace industry [43].

WinSun is a Chinese company that worked jointly with architectural and structural design companies such as Killa Design to build an office building for the Dubai Future Foundation Fig. 13. They used an additive concrete 'printing' technique to manufacture the entire structure of the building, by using a 3D printer 20 feet high, 120 feet long and 40 feet wide. The building was printed in Shanghai, shipped to Dubai, and then assembled on site. The cost of printing and assembling was around $\$ 140,000$ for the $242 \mathrm{~m} 2$. The process of printing lasted 17 days and was installed on site in two days. Subsequent work on the building services, interiors, and landscape took approximately three months.
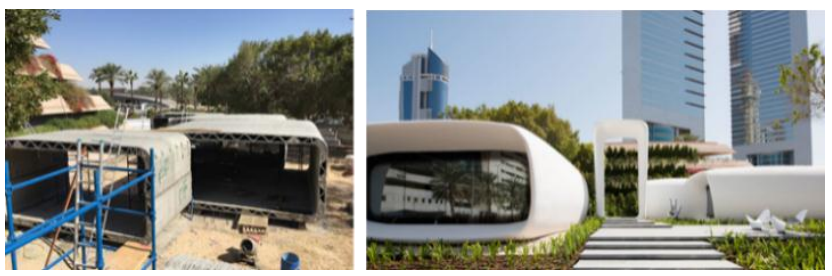

Fig. 13. 3D printed building parts assembly(left) office building after finishing(right)[44].
As a result of this innovative construction technique, the labour cost was cut by more than $50 \%$ compared to conventional buildings of similar size, and waste was reduced by 30 to $60 \%$ which helped to reduce the overall environmental footprint of the project. [44]

Apis Cor is the developer company of unique mobile construction $3 \mathrm{D}$ printer that works in polar coordinates. In just 24 hours, the company was able to construct a house, with a 400 -square-foot-home being built from scratch in Moscow Fig. 14. This is the first residential house 3Dprinted onsite with a mobile printer, it costs $\$ 10,134$. All the walls and foundations of this structure were printed with a concrete mixture and other parts such as windows, fixtures and furniture being added after construction. The company says that the house can last 175 years and withstand tough weather conditions [45].
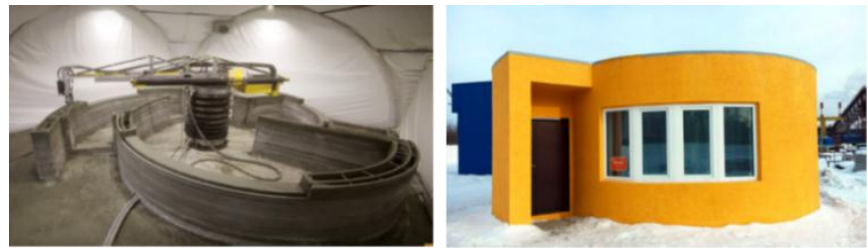

Fig. 14. House during printing process (left) final product after finishing and painting[45].

Comparing to with conventional method of construction, 3D Apis Cor machine saved a lot of time and materials used in the construction process, in addition to reducing the percentage of waste resulting from construction and reducing the proportion of labour and its costs. It has limited the stages of the construction process, which gives preference to emerging technology.

According to previous examples, we can summarize Advantages of $3 \mathrm{~d}$ printing concrete technology:

- Freedom of form. With 3D concrete printing, complex concrete structures are possible.

- $\quad$ Reduce waste of material.

- $\quad$ Printing of different types, qualities and colours of the concrete wall with a lot of features, such as wall reinforced with fibres of wire, outside kept dirt-repellent, contains the internal drainage pipes of waterproof concrete and Soundproof cavities.

- Mass customization, it is the possibility to process individual wishes per individual customer.

- Reducing construction time.

- Reducing construction costs.

- Reducing labour

In addition to, there are some disadvantages of this technology:

- Cost of the printer is high, and maintenance procedures cost.

- The printing is limited on specific elements (walls and foundations). 
- Modification limitations. It is impossible to accept any change orders during printing process.

\subsubsection{STIRRUPS ROBOT (MEP | Aron-Robotic Solutions)}

MEP Group is a leading company in the rebar equipment manufacturing and in resistance welding technology, has been on the market since 1967. MEP developed a lot of products. ARON is one of these products, has been developed by DHL (Daehansteel networks) Fig.15 [33].

ARON is a fully automatic solution developed and launched based on the strengths of both companies. From the GSA system (grid straightening adjustment) to the packing and tagging, MEP reached the highest level of performances in term of productivity, quality and safety[33].

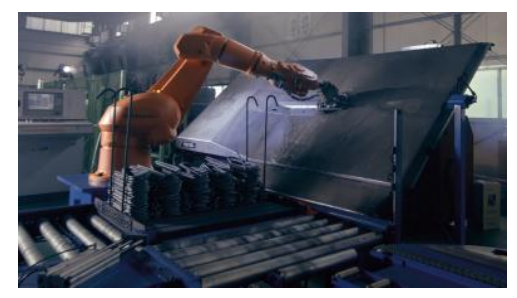

Fig.15. MEP | Aron - Robotic Solutions[33].

ARON is an optimizing solution that allows a robotcontrolled, fully automated cut and bend rebar production utilizing bars in a coil. Bars in coil, the starting point of the Aron solution, are compact rolls. That saves space and can be automatically cut into the desired length, and thus maximizes storage and transportation efficiency.

Through the automated one-stop production, bars of any shape and length can be manufactured according to the different needs each time. This reduces cutting losses and increases productivity. The robot can produce rebars 24/7 and therefore not only minimize labor and equipment cost but also increase productivity by 150 to $200 \%$.

In rebar production, correction is a highly important element that directly impacts quality. Aron operates on a grid-vision straightening adjustment system. The GSA system performs excellent straightening adjustment on a new level and also boosts productivity by reducing the time needed for correction by more than $70 \%$. Aron can be installed both in factories as well as on-site[34].

\subsubsection{Automatic Rebar Bundling Robot (T-iROBO Rebar)}

CHIBA Institute of Technology and Taisei Corporation have teamed up to develop an autonomous rebar robot, which called T-iROBO Rebar Fig.16. The robot has been developed to improve work efficiency and productivity in the Reinforcement Steel Placement Work, which is one of the frameworks of building construction. Issues such as the aging of skilled workers (rebar workers) and labor shortage have also become increasing[35].

T-iROBO Rebar automatically repeats rebar bundling and working to fasten intersecting rebars with wires, which accounts for about $20 \% *$ of rebar construction[36].

T-iROBO Rebar enables repetition of rebar binding operation accurately, increases productivity and improve efficiency. In addition to reducing costs of skilled construction workers and the risk of delay in a project due to the lack of workforce[35].

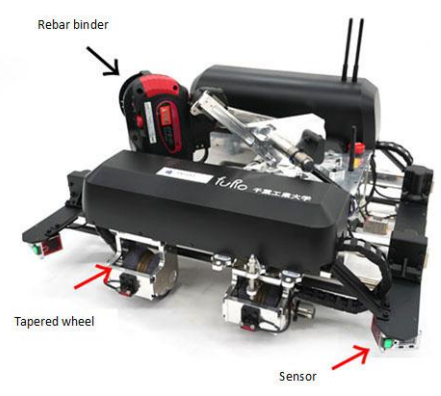

Fig.16. T-iROBO Rebar Main components [35].

The features of T-iROBO Rebar are as follows[36]:

- The robot is automatically using two types of laser sensors installed on its body, to detect the crossing section of steel bars and positions of obstacles.

- Adopting a new movement mechanism, the robot can move stably in four directions on rebar structure.

- T-iROBO Rebar enables about $20 \%$ of labor saving, in addition to improving work efficiency by $10-20 \%$ of the whole project.

- The robot is compact (about $40 \mathrm{~cm} \times 50 \mathrm{~cm} \times$ $30 \mathrm{~cm}$ ) and light (under $20 \mathrm{~kg}$ ), and can be easily carried by a single worker.

\subsubsection{Mobile Drilling Robot}

Several companies have recently developed or was in the process of developing robotic solutions to automate conventional building technology. For example, nLink designs and develops mobile robots that solves real-life problems, replacing repetitious work tasks in difficult and dangerous environments. nLink are introducing the first commercial mobile drilling robot to the construction industry. The firm claims that their robots are efficient, customized for working on construction sites, increases worker safety and ensures a faster project completion.

The ceiling drilling robot works with electricity from a power cable, and drives on battery. To collect dust, debris and protect the health of workers, a vacuum cleaner is installed in the robot. The robot weighs $850 \mathrm{~kg}$ when it is 
fully uploaded for the set-up. Approximately, the weight is $800 \mathrm{~kg}$, When the robot operates. The robot connects with the total station by using two prisms. Fig. 5 is a technical drawing from nLink that define components of the robot Fig. $17[41]$.

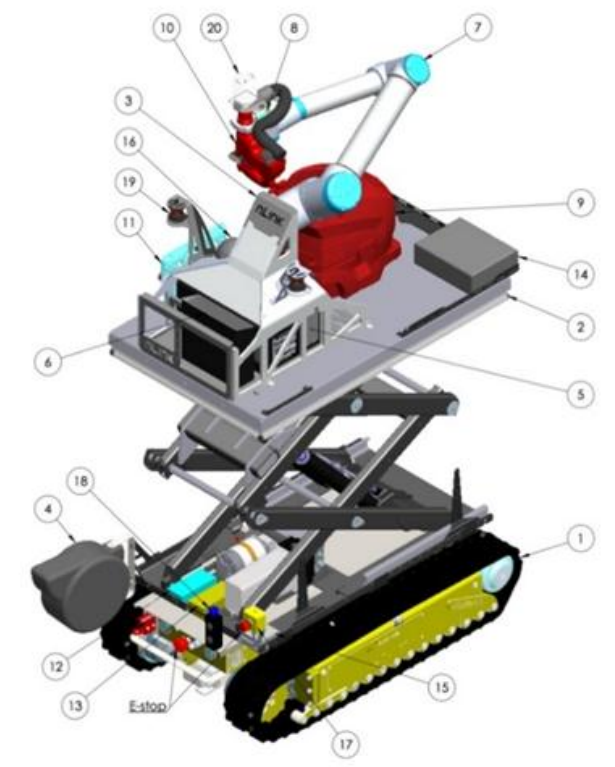

\begin{tabular}{|c|c|c|}
\hline MEM NO. & DESCRIPTON & TYPE \\
\hline 1 & TRACKS & AUTRAK, DCT-45O \\
\hline 2 & SCISSOR UFT & EDMOUF, nLD-1000 \\
\hline 3 & TOP FRAME & NUINK \\
\hline 4 & CABLE REEL & \\
\hline 5 & ROBOT CONTROL BOX & UNIVERSAL ROBOTS / NUINK \\
\hline 6 & 30 CAMERA SYSTEM & SCORPION, 3D STINGER \\
\hline 7 & ROBOT ARM & UNIVERSAL ROBOTS, URIO \\
\hline 8 & HOLE DEPTH MEASURING & $\begin{array}{l}\text { PEPPERL-FUCHS. VDM18- } \\
300 / 32 / 105 / 122\end{array}$ \\
\hline 9 & VACUUM CLEANER & HILT, VC2O-U \\
\hline 10 & ROTARY HAMMER & HILn, TEY \\
\hline 11 & ROBOT ARM CONTROL PENDANT & UNIVERSAL ROBOTS \\
\hline 12 & TOTAL STATION CHARGER & LECA \\
\hline 13 & TRACK CONTROLLER CHARGER & AUTRAK \\
\hline 14 & IPAD CHARGE BOX & NUNK \\
\hline 15 & JUNCTON BOX & NUNK \\
\hline 16 & WIFl, 4G, GPS ANTENNA & $\begin{array}{c}\text { TAOGLAS UIMITED, PANTHEON } 3 \text { IN } \\
\text { I GPS LIE }\end{array}$ \\
\hline 17 & EMERGENCY STOP BUTTON & BACO \\
\hline 18 & SCISSOR UFT CONTROULR & DEMOUFT \\
\hline 19 & PRISME & LECA \\
\hline \multirow[t]{2}{*}{20} & VACUUM CUP & \\
\hline & STEEL BRACKEIS & NUNK \\
\hline
\end{tabular}

Fig. 17. nLink mobile drilling robot technical information [41].

According to theoretical study, the operational time shows that the installer can save up to 33 percent of his net cycle time by using the pre-drilled holes from the robot. The study approves that the potential time savings by using the robot could possibly be more effective with a locationbased schedule. Robots may take more time or face problems during work at areas with a lot of temporary or permanent storage.

In addition to drilling holes in the ceiling, the mobile construction robot can also perform other tasks, placing a plastic plug for screws, or a hook for ceilings or lights. Additionally, holes can be drilled in the wall or floor.[42]

One of the benefits of drilling robot, that the predrilling reduces the worker's risk of injury and worker's shoulder strain, due to simplifying the installation work. In addition to benefits within reducing noise, dust and clean workplaces. Two biggest and essential disadvantages are the cost of the robot; it is too expensive compared to the benefits and the problematic of completing the drilling in areas with a lot of temporary or permanent storage.

\subsubsection{Humanoid Robot Prototype HRP-5P}

(AIST) The National Institute of Advanced Industrial Science and Technology have developed a humanoid robot prototype, HRP-5P, intended to autonomously perform heavy labour or work in hazardous environments. Humanoid Robots can work without requiring environmental changes to be suitable to them, because humanoid robots physically resemble people.

The humanoid robot prototype HRP-5P was designed with a sturdy body and advanced intelligence to work as an alternative source of heavy labour, such as handling and installation large objects such as gypsum boards $(1820 \times$ $910 \times 10 \mathrm{~mm}$, approx. $11 \mathrm{~kg})$ or plywood panels $(1800 \times$ $900 \times 12 \mathrm{~mm}$, approx. $13 \mathrm{~kg}$ ) Fig. 18 [37] .

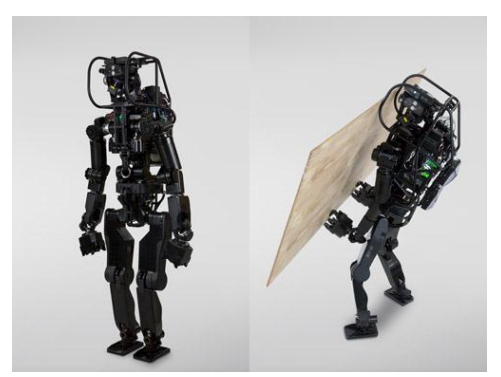

Fig. 18. HRP-5P appearance (left) and HRP-5P carrying an approx. $13 \mathrm{~kg}$ board (right)[37].

As a $182 \mathrm{~cm}, 101 \mathrm{~kg}$ humanoid robot, HRP-5P has a body with a total of 37 degrees of freedom: two in its neck, three in its waist, eight in its arms, six in its legs, and two in its hands. The researchers developed areas where multiple joints are concentrated like joints in the hip and waist areas, to ensure a wider movable rather than human. For example, hip joints that flex and extend the legs have a range of motion of $140^{\circ}$ in humans and $202^{\circ}$ in HRP-5P and waist joints that turn the upper body have a range of motion of $80^{\circ}$ in humans and $300^{\circ}$ in HRP-5P Fig. 19 [40] .

HRP-5P constantly acquires 3D measurements of the surrounding environment, by using head - sensors. Updated measurement results enable the robot to avoid objects, which block the field of view and execution of the walking plan while carrying a panel Fig. 20. 


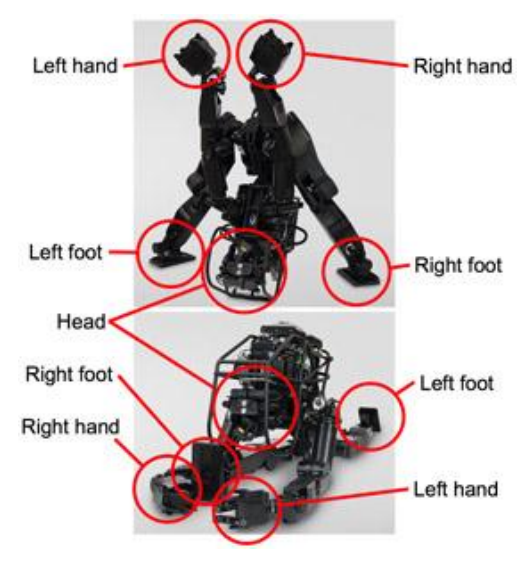

Fig. 19. Bending forward (top) and with legs spread forward and back (bottom)[40].

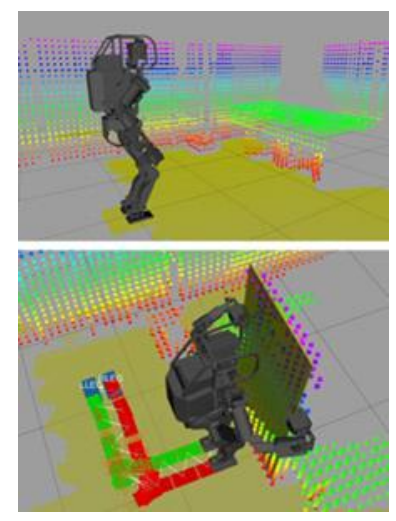

Fig. 20. Map of surrounding area (top) and walking plan (bottom)[40].

The robot can recognize on ten types of $2 \mathrm{D}$ object regions at a high precision of $90 \%$ or more even in a poorly light work environment by using a newly constructed image database of work objects. This technology enables completing the transportation of large gypsum panels and heavy objects easily and installing them with precision, relying on high-precision sensors in determining movement and objects.[40] The Humanoid robot is not fast but is extremely methodical. What it lacks in speed, it makes up for in its caution and meticulousness.

\subsubsection{OKIBO - wall plastering robot demonstration}

OKIBO is developing intelligent, mobile, multi-purpose and autonomous robots for use in construction sites. Developed smart robotics for wall plastering putting and painting. It is designed to have a mobile platform with Kuka arm attached with a nozzle rendering and paint tool, the robot can change between them according to the task Fig. 21 [37] [38].

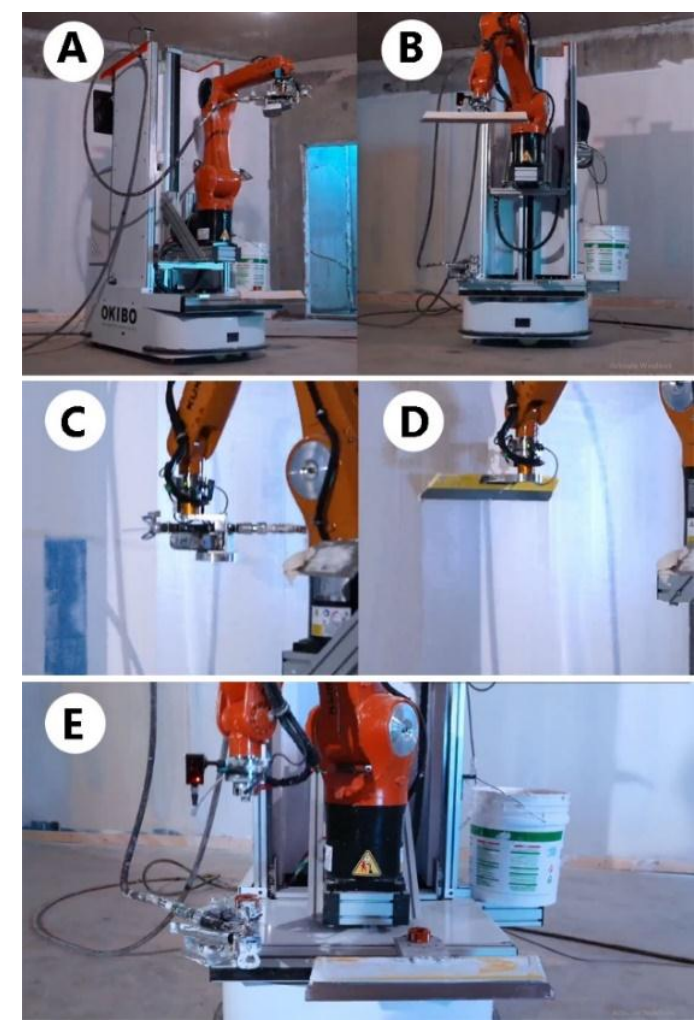

Fig. 21. (A, C) Spray tool, (B, D) Paint tool, (E) automatic changing tools[38].

The robot performs top quality plastering jobs in a fraction of the time spent in conventional plastering methods, due to robustness of the industrial robotic arms. The automation of the robot prevents the exposure of human workers to potential risks, such as working in heights and working with toxic materials. The robot can generate $3 \mathrm{D}$ mapping its environment, by using high accurate $3 \mathrm{~d}$ scanning. This enables progress monitoring, BIM comparison and reliable understanding of the plastering requirements. [39].

\subsubsection{Under water Robots (DTG3 ROV)}

Deep Trekker provides remotely operated vehicles (ROVs) portable, and easy to use such as, submersible crawler systems and subsurface cameras. Deep Trekker robots can be employed in industries ranging from aquaculture to commercial diving, recreation, military, search and rescue, shipping, infrastructure inspections and more [46].

DTG3 is one of underwater remotely operated vehicles (ROV) Proven, durable and portable Fig.22, built to provide operators the ability to quickly deploy and visually inspect within underwater environments. Deep Trekker Produced DTG3 to be suited for inspections of hydroelectric dams, this operation requires contracting with commercial dive teams. Working in these environments is dangerous so safety is crucial. Calling on divers to perform visual inspections is costly and can be time consuming[47]. 


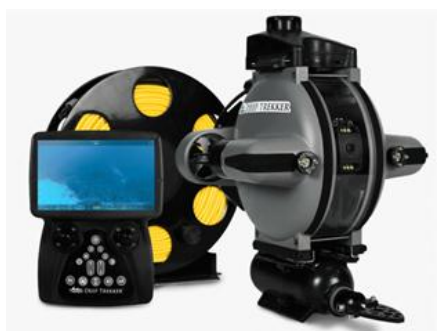

Fig. 22. DTG3 underwater remotely operate vehicles [48].

Robot able to examine many structure areas at dam site. There are some areas of applications, where Deep Trekker ROV was employed:

- Reservoir, there are structures containing the water such as walls and lake beds that need to be evaluated, whether it is to monitor sediment levels or structural integrity.

- Intake / control gate, the internal structures (turbine) need to remain in good shape, the gate that prevents large objects from entering the intake and causing damage to the turbine needs to be inspected regularly for blockages and for their condition (which can reduce flow and electrical output).

- Trash racks, where objects gather around the edges of a dam. Deep Trekker ROV can ensure regularly survey and also contribute in clearance operations by using the Grabber. The Grabber combined with pulling on the tether can lift up to $90 \mathrm{~kg}$ (200 lbs).

- Penstocks, they are an important part to maintain and monitoring. If these have a blockage. This can reduce efficiencies and may have environmental impacts.
DTG3 depend on the ultra-short baseline (USBL) system to indicate the position of the ROV. Wi-Fi enabled maps allow you to see where both the controller and the ROV are located on a detailed map. Robot come with full HD internal camera, with live zero latency viewing on the handheld controller and a 270-degree rotating field of view. Switch to photo mode to snap photos up to 8 megapixels[48].

According to Deep Trekker, we can summarize Advantages of DTG3[47]:

- $\quad$ Saving Time, costs of inspections and follow-up

- Less labour and risk involved.

- Robust and reliable.

- Affordable and easy to operate.

- low maintenance and do not require extensive training or retraining for operations compared to other ROVs.

Disadvantages:

- Depth Rating to $200 \mathrm{~m}$

- $\quad$ it is very expensive for providing service.

- The robot is connecting with a cable to transmit the signal and data.

\section{Advantages and Disadvantages}

According to previous applications for some Robots examples in construction field and what has been reviewed of the advantages of these robots and some of their shortcomings comparing to traditional building technology, they can be summarized in the table (1) to identify most important advantages, disadvantages, and common points between them. In addition to, Clarifying area of employing, Company, Price and Release Date.

Table (1) Main advantages and disadvantages of robots in construction. By Author

\begin{tabular}{|c|c|c|c|c|c|c|c|}
\hline : & 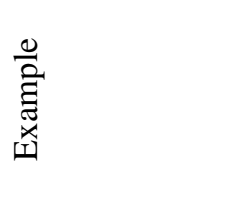 & Advantages & Disadvantages & 苮 & 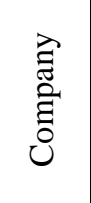 &.$\stackrel{\mathscr{U}}{0}$ & 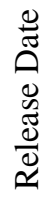 \\
\hline \multirow{3}{*}{ 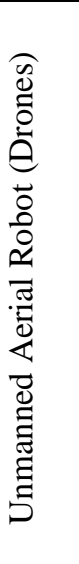 } & $\begin{array}{l}\text { (Boomerang) } \\
\text { Mapping }\end{array}$ & \multirow{3}{*}{$\begin{array}{l}\text { - Using in large sites. } \\
\text { - Multi-tasking[18]. } \\
\text { - Be a safer, cheaper, faster, and } \\
\text { more accurate method for } \\
\text { surveying and mapping[20]. } \\
\text { - Capture various data. } \\
\text { - Using to aid planning, design, } \\
\text { construction and } \\
\text { maintenance[22]. } \\
\text { - Moving long distances[23]. }\end{array}$} & \multirow{3}{*}{$\begin{array}{l}\text { - Limitation is the payload } \\
\text { problem. } \\
\text { - More affected by weather } \\
\text { factors. } \\
\text { - A distraction source for the } \\
\text { employment on the site[21]. } \\
\text { - Limitation of flying time; some } \\
\text { missions may not be done with } \\
\text { one time flying. } \\
\text { - Need professional trainings[22]. }\end{array}$} & \multirow{3}{*}{ 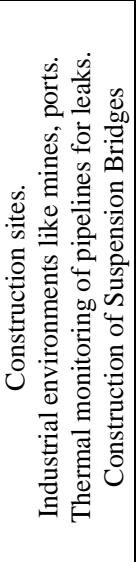 } & 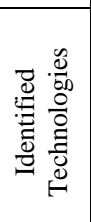 & 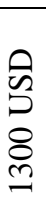 & $\frac{m}{0}$ \\
\hline & $\begin{array}{c}\text { Pilot Lines of } \\
\text { Suspension Bridges }\end{array}$ & & & & 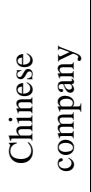 & $\frac{\nwarrow}{\mathrm{Z}}$ & $\overline{\bar{c}}$ \\
\hline & Monitoring & & & & 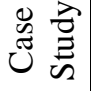 & $\frac{\nwarrow}{\text { Z }}$ & 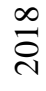 \\
\hline
\end{tabular}




\begin{tabular}{|c|c|c|c|c|c|c|c|}
\hline \multirow{4}{*}{ 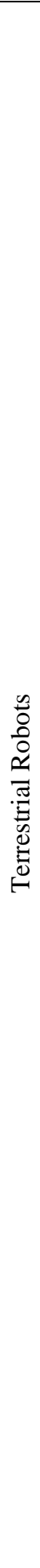 } & $\begin{array}{l}\text { Demolition Robots } \\
\text { (DXR 310) }\end{array}$ & $\begin{array}{l}\text { - Easy to transport. } \\
\text { - More efficient. } \\
\text { - Demolition in most types of } \\
\text { material. } \\
\text { - Ideal for demolishing bricks } \\
\text { and concrete[28]. } \\
\text { - More secure to save labor. } \\
\text { - Remote controlled. } \\
\text { - More accurate and flexible. } \\
\text { - Saving time and working with } \\
\text { the difficult environment [26]. }\end{array}$ & $\begin{array}{l}\text { - Initial cost. } \\
\text { - Operation needs to professionals } \\
\text { with experience[29]. } \\
\text { - Still scatter dust particles into } \\
\text { air. } \\
\text { - Maintenance cost. } \\
\text { - Tool's price. } \\
\text { - Challenge of training } \\
\text { operators[30]. }\end{array}$ & 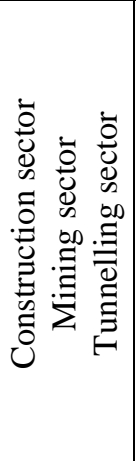 & 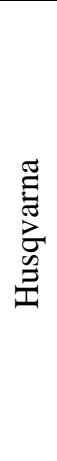 & 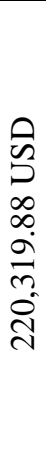 & \\
\hline & $\begin{array}{l}\text { Mobile Robotic } \\
\text { Brickwork }\end{array}$ & $\begin{array}{l}\text { - Increase mason's productivity } \\
\text { by } 3-5 x \text {. } \\
\text { - More Accurate by using laser } \\
\text { and sensors. } \\
\text { - complete tasks at a rate that is } \\
\text { five to six times faster than a } \\
\text { masonry crew. } \\
\text { - Less labour needed[31]. }\end{array}$ & $\begin{array}{l}\text { - not fully automate. } \\
\text { - Initial cost[11]. } \\
\text { - needs to be perfectly levelled. } \\
\text { - Building straight wall. } \\
\text { - Smaller masonry projects do not } \\
\text { seem fit for the SAM100 [31]. }\end{array}$ & 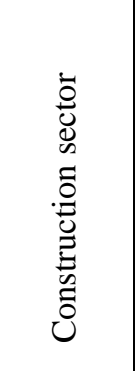 & 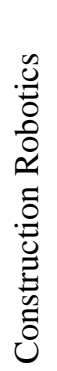 & $\begin{array}{l}8 \\
8 \\
8 \\
8 \\
\wp\end{array}$ & $\stackrel{\searrow}{Ð}$ \\
\hline & 3D Printing Concrete & $\begin{array}{l}\text { - Freedom of form with 3D } \\
\text { concrete printing, complex } \\
\text { concrete structures are possible. } \\
\text { - Reduce waste of material. } \\
\text { - Printing of different types, } \\
\text { qualities and colours of the } \\
\text { concrete wall[45]. } \\
\text { - Mass customization. } \\
\text { - Reducing construction time. } \\
\text { - Reducing construction costs. } \\
\text { Reducing labour[44]. }\end{array}$ & $\begin{array}{l}\text { - Cost of the printer is high, and } \\
\text { maintenance procedures cost. } \\
\text { - The printing is limited on } \\
\text { specific elements (walls and } \\
\text { foundations). } \\
\text { Modification limitations, it is } \\
\text { impossible to accept any change } \\
\text { orders during printing } \\
\text { process[45]. }\end{array}$ & 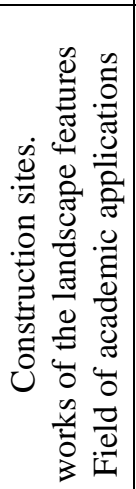 & $\begin{array}{l}0 \\
0 \\
0 \\
0\end{array}$ & 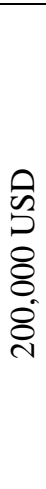 & $\stackrel{\infty}{\infty}$ \\
\hline & $\begin{array}{l}\text { STIRRUPS ROBOT } \\
\text { (MEP | Aron - } \\
\text { Robotic Solutions) }\end{array}$ & $\begin{array}{l}\text { - ARON is a fully automated. } \\
\text { - highest level of productivity, } \\
\text { quality and safety[33]. } \\
\text { - Increasing productivity by } 150 \\
\text { to } 200 \% \text {. } \\
\text { - reducing the time needed for } \\
\text { correction by more than } \\
70 \%[34] \text {. }\end{array}$ & - Not available & $\begin{array}{l}\dot{0} \\
0 \\
0 \\
0 \\
0 \\
0 \\
.0 \\
0 \\
0 \\
0 \\
0 \\
0 \\
0\end{array}$ & 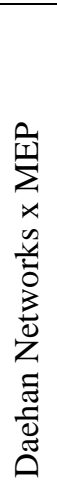 & $\frac{\nwarrow}{Z}$ & $\frac{\infty}{\grave{N}}$ \\
\hline
\end{tabular}




\begin{tabular}{|c|c|c|c|c|c|c|}
\hline $\begin{array}{l}\text { Automatic Rebar } \\
\text { Bundling Robot (T- } \\
\text { iROBO Rebar) }\end{array}$ & $\begin{array}{l}\text { - increases productivity. } \\
\text { - reducing cost. } \\
\text { - Reducing the risk of delay in a } \\
\text { project[35]. } \\
\text { - Moving stably in four } \\
\text { directions. } \\
\text { - improving work efficiency by } \\
10-20 \% \text { of the whole project. } \\
\text { - The robot is compact and light, } \\
\text { can be easily carried [36]. }\end{array}$ & $\begin{array}{l}\text { - It only works on horizontal } \\
\text { levels [35]. }\end{array}$ & 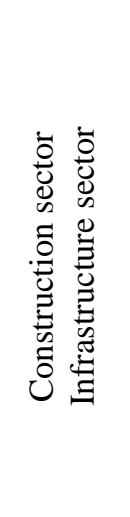 & 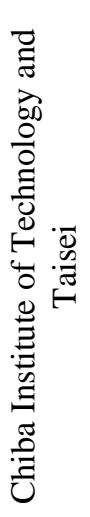 & $\frac{\nwarrow}{Z}$ & 궁 \\
\hline Mobile Drilling Robot & $\begin{array}{l}\text { - More efficient \& accurate on } \\
\text { construction sites. } \\
\text { - Increases worker safety. } \\
\text { - ensure a faster project } \\
\text { completion. } \\
\text { - Working with electricity and } \\
\text { deriving on battery[41]. } \\
\text { - It has a vacuum cleaner to } \\
\text { collect dust and debris. } \\
\text { - The robot performs other tasks, } \\
\text { placing a plastic plug for } \\
\text { screws, or a hook for ceilings or } \\
\text { lights. } \\
\text { - holes can be drilled in the wall } \\
\text { or floor. } \\
\text { - Reduce the worker's risk of } \\
\text { injury[42]. }\end{array}$ & $\begin{array}{l}\text { - Robot weighs is } 850 \mathrm{~kg}[41] \text {. } \\
\text { - Robots take more time or face } \\
\text { problems during work at areas } \\
\text { with a lot of temporary or } \\
\text { permanent storage. } \\
\text { - Give less room for adjustments } \\
\text { in installation phase[42]. }\end{array}$ & 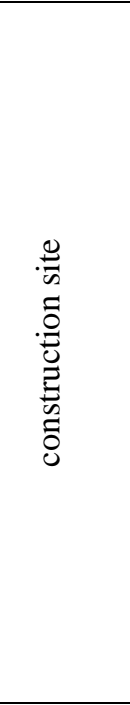 & 光 & $\overleftrightarrow{\mathrm{z}}$ & $\frac{n}{2}$ \\
\hline $\begin{array}{l}\text { Humanoid Robot } \\
\text { Prototype HRP-5P }\end{array}$ & $\begin{array}{l}\text { - Works with various } \\
\text { environments. } \\
\text { - Designed with a sturdy body } \\
\text { and advanced intelligence[37]. } \\
\text { - Handling and installation large } \\
\text { objects. } \\
\text { - It has a total of } 37 \text { degrees of } \\
\text { freedom. } \\
\text { - recognize on ten types of } 2 \mathrm{D} \\
\text { object regions at a high } \\
\text { precision of } 90 \%[40] \text {. }\end{array}$ & - Prototype under study & 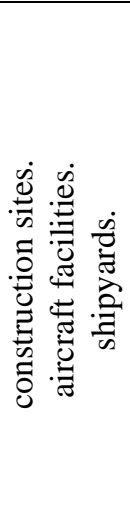 & 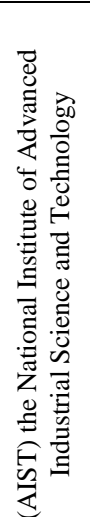 & 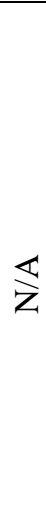 & $\stackrel{\infty}{\infty}$ \\
\hline
\end{tabular}




\begin{tabular}{|c|c|c|c|c|c|c|c|}
\hline & Wall plastering robot & $\begin{array}{l}\text { - Decreasing time of plastering } \\
\text { putting and painting comparing } \\
\text { to conventional methods. } \\
\text { - prevents human workers to } \\
\text { potential risks. } \\
\text { - Generate 3D mapping its } \\
\text { environment. } \\
\text { - automatic changing spray and } \\
\text { paint tool. } \\
\text { work autonomously \& can keep } \\
\text { working } 24 / 7[38][39] .\end{array}$ & Not available & 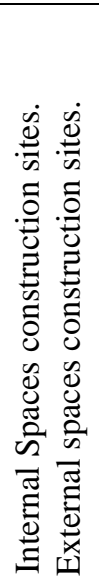 & 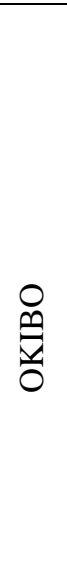 & $\underset{\mathrm{Z}}{\varangle}$ & ণ્ડે \\
\hline 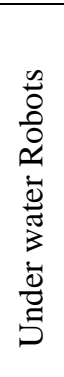 & DTG3 ROV & $\begin{array}{l}\text { - Robots can be employed in } \\
\text { multiple industries[46]. } \\
\text { - Saving Time, costs of } \\
\text { inspections and follow-up. } \\
\text { - Provide safety and safe } \\
\text { labour[47]. } \\
\text { - Affordable and easy to operate. } \\
\text { - low maintenance and do not } \\
\text { require extensive training[48]. }\end{array}$ & $\begin{array}{l}\text { Depth Rating to } 200 \mathrm{~m} \text {. } \\
\text { - It is very expensive for } \\
\text { providing service. } \\
\text { - The robot is connecting with a } \\
\text { cable to transmit the signal and } \\
\text { data[47]. }\end{array}$ & 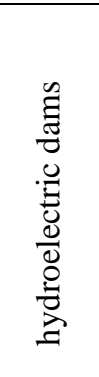 & 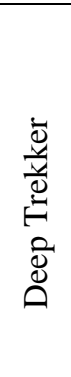 & 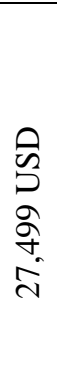 & $\stackrel{ }{\stackrel{2}{2}}$ \\
\hline
\end{tabular}

\section{SWOT analysis}

Based on the previous table of advantages and disadvantages of employing robots in construction, we can determine the potentials and constrains of employing the previous example of robots in construction in Egypt by using a SWOT analysis tool table (2). a SWOT analysis was conducted. $\mathrm{t}$ is the most convenient method that assists in making decisions and developing strategic plans on a logical basis.

Table (2) SWOT analysis of employing robots in construction in Egypt for each previous example. By Author

\begin{tabular}{|c|c|c|c|c|c|}
\hline \multirow{3}{*}{ 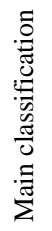 } & \multirow{3}{*}{ 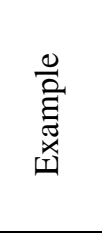 } & \multicolumn{4}{|c|}{ Employing robots in construction in Egypt } \\
\hline & & \multicolumn{4}{|c|}{ SWOT ANALYSIS } \\
\hline & & Strengths & Weaknesses & Opportunities & Threats \\
\hline 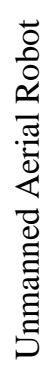 & 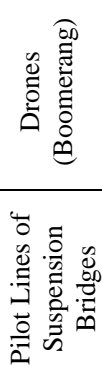 & $\begin{array}{l}\text { - Multi- tasking. } \\
\text { - More efficient and less } \\
\text { expensive than } \\
\text { traditional methods of } \\
\text { data gathering and } \\
\text { surveying. } \\
\text { - Save operation time. } \\
\text { - More accurate for } \\
\text { collecting data. }\end{array}$ & $\begin{array}{l}\text { - professional operators } \\
\text { are indispensable for } \\
\text { the use of drones in } \\
\text { construction. } \\
\text { - More affected by } \\
\text { weather factors. } \\
\text { - Construction workers } \\
\text { can be distracted by a } \\
\text { flying drone during }\end{array}$ & $\begin{array}{l}\text { - Applying in many } \\
\text { fields and tasks. } \\
\text { - Increase BIM Using. } \\
\text { - Increase speed of } \\
\text { transfer and analysis } \\
\text { data. } \\
\text { - Open new market in } \\
\text { construction } \\
\text { technology. }\end{array}$ & $\begin{array}{l}\text { - Local regulations. } \\
\text { - Weather conditions } \\
\text { such as strong winds } \\
\text { and } \\
\text { rains. } \\
\text { - Using in spying } \\
\text { applications. }\end{array}$ \\
\hline
\end{tabular}




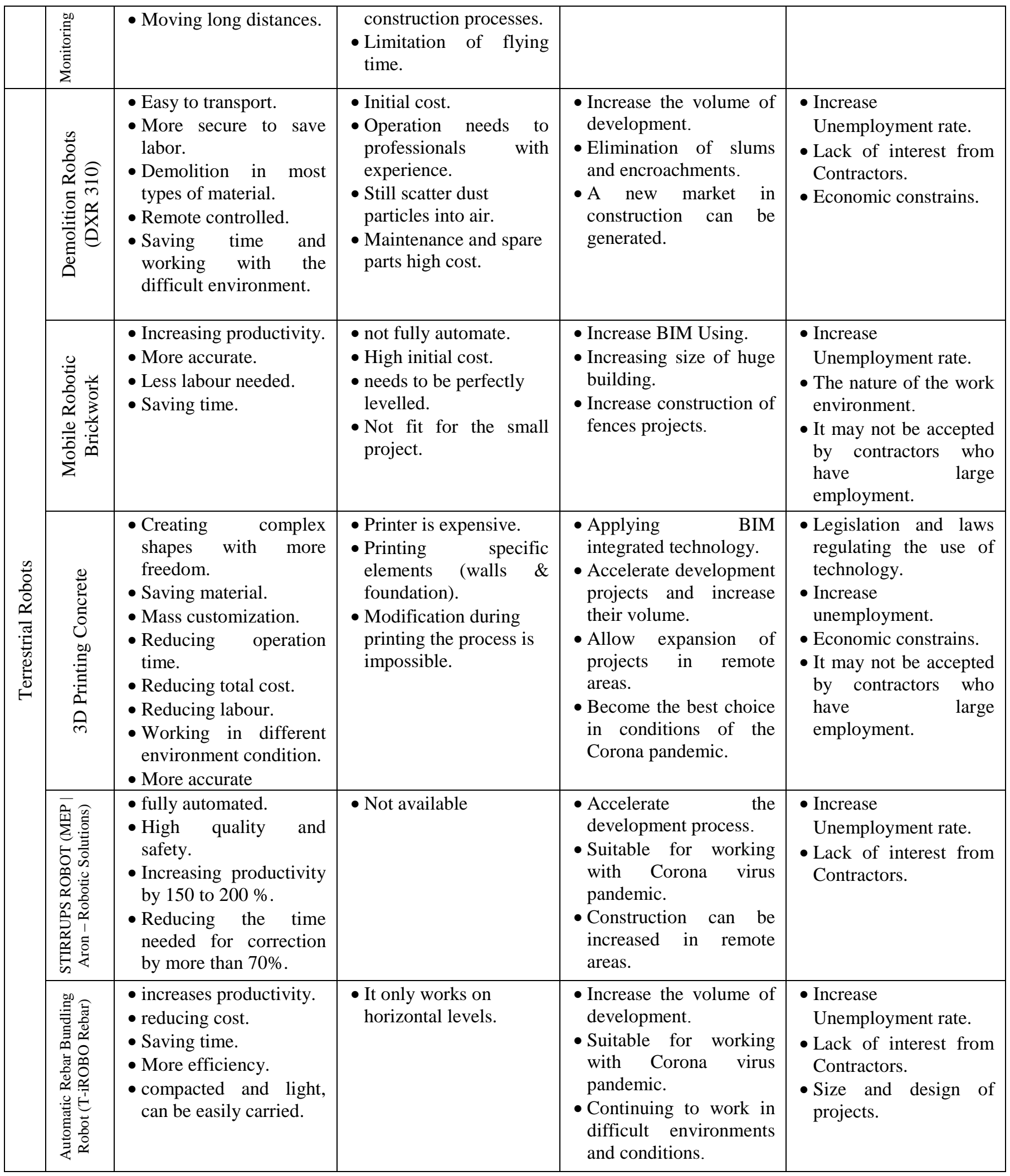




\begin{tabular}{|c|c|c|c|c|c|}
\hline & 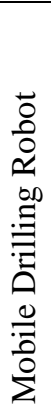 & $\begin{array}{l}\text { - Saving time of drilling } \\
\text { and installation } \\
\text { operation. } \\
\text { - Doing other tasks. } \\
\text { - More accurate. } \\
\text { - Drilling in the wall and } \\
\text { floor. } \\
\text { - Reduce the worker's } \\
\text { risk of injury. }\end{array}$ & $\begin{array}{l}\text { - Weight of the robot is } \\
800 \mathrm{~kg} \text {. } \\
\text { - Affected by working at } \\
\text { areas with a lot of } \\
\text { temporary. } \\
\text { - Cost of the robot is too } \\
\text { expensive. } \\
\text { - Not flexible enough for } \\
\text { modification. }\end{array}$ & $\begin{array}{l}\text { - contribute to accelerate } \\
\text { the use of BIM. } \\
\text { - Extra quality control of } \\
\text { design in BIM }\end{array}$ & $\begin{array}{l}\text { - Extra cost due to BIM } \\
\text { model more details. } \\
\text { - Bigger consequences } \\
\text { of wrong design. } \\
\text { - Increase } \\
\text { Unemployment. } \\
\text { - Difficult to convince } \\
\text { the sub-contractors. }\end{array}$ \\
\hline & 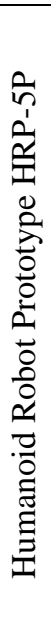 & $\begin{array}{l}\text { - Humanoid robots } \\
\text { physically resemble } \\
\text { people. } \\
\text { - It has a sturdy body. } \\
\text { - It relies on Artificial } \\
\text { intelligence. } \\
\text { - Handling and } \\
\text { installation large } \\
\text { objects. } \\
\text { - Joints have a wider } \\
\text { movable rather than } \\
\text { human. } \\
\text { - Recognize on tools } \\
\text { even in a poorly light } \\
\text { work environment. }\end{array}$ & $\begin{array}{l}\text { - Still under study. } \\
\text { - Limitation of work } \\
\text { tasks. } \\
\text { - Not fast enough } \\
\text { compared to the worker }\end{array}$ & $\begin{array}{l}\text { - It can be applied for } \\
\text { multi-tasking. } \\
\text { - Suitable for working } \\
\text { with Corona virus } \\
\text { pandemic. } \\
\text { - Construction can be } \\
\text { increased in remote } \\
\text { areas. }\end{array}$ & $\begin{array}{l}\text { - Increase } \\
\text { Unemployment rate. } \\
\text { - Lack of interest from } \\
\text { Contractors. }\end{array}$ \\
\hline & 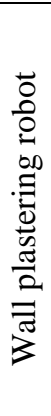 & $\begin{array}{l}\text { - Work autonomously } \\
24 / 7 . \\
\text { - automatic changing } \\
\text { spray and paint tool. } \\
\text { - Decreasing time of } \\
\text { plastering operation. } \\
\text { - Saving human from } \\
\text { risks due to, working in } \\
\text { heights with toxic } \\
\text { materials. }\end{array}$ & - Not available & $\begin{array}{l}\text { - increasing the size of } \\
\text { projects and speeding } \\
\text { up their completion. }\end{array}$ & $\begin{array}{l}\text { - Increase } \\
\text { Unemployment rate. } \\
\text { - It may not be accepted } \\
\text { by contractors who } \\
\text { have large } \\
\text { employment. }\end{array}$ \\
\hline 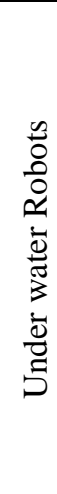 & 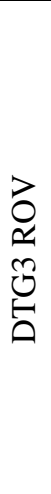 & $\begin{array}{l}\text { - Saving time and costs. } \\
\text { - Less labour and risk } \\
\text { involved. } \\
\text { - Affordable and easy to } \\
\text { operate. } \\
\text { - available maintenance } \\
\text { and training. } \\
\text { - giving accurate data. } \\
\text { - It has Grabber } \\
\text { combined with pulling } \\
\text { on the tether can lift up } \\
\text { to } 90 \mathrm{~kg} \text {. }\end{array}$ & $\begin{array}{l}\text { - Relatively expensive. } \\
\text { - Depth Rating } 200 \mathrm{~m} \text {. } \\
\text { - The robot is connecting } \\
\text { with a cable to transmit } \\
\text { the signal and data. }\end{array}$ & $\begin{array}{l}\text { - Reducing the chances } \\
\text { of problems occurring. } \\
\text { - It can contribute to } \\
\text { underwater } \\
\text { construction. } \\
\text { - It can contribute to port } \\
\text { development } \\
\text { operations. } \\
\text { - It can contribute to } \\
\text { monitor the water oil } \\
\text { fields. }\end{array}$ & $\begin{array}{l}\text { - Local regulations. } \\
\text { - It may be used for } \\
\text { illegal actions. }\end{array}$ \\
\hline
\end{tabular}

The table (3) shows an overview of the SWOT analysis of application robots on construction in Egypt instead of traditional method. 
Table 3. SWOT analysis of using robots in construction in Egypt. By Author

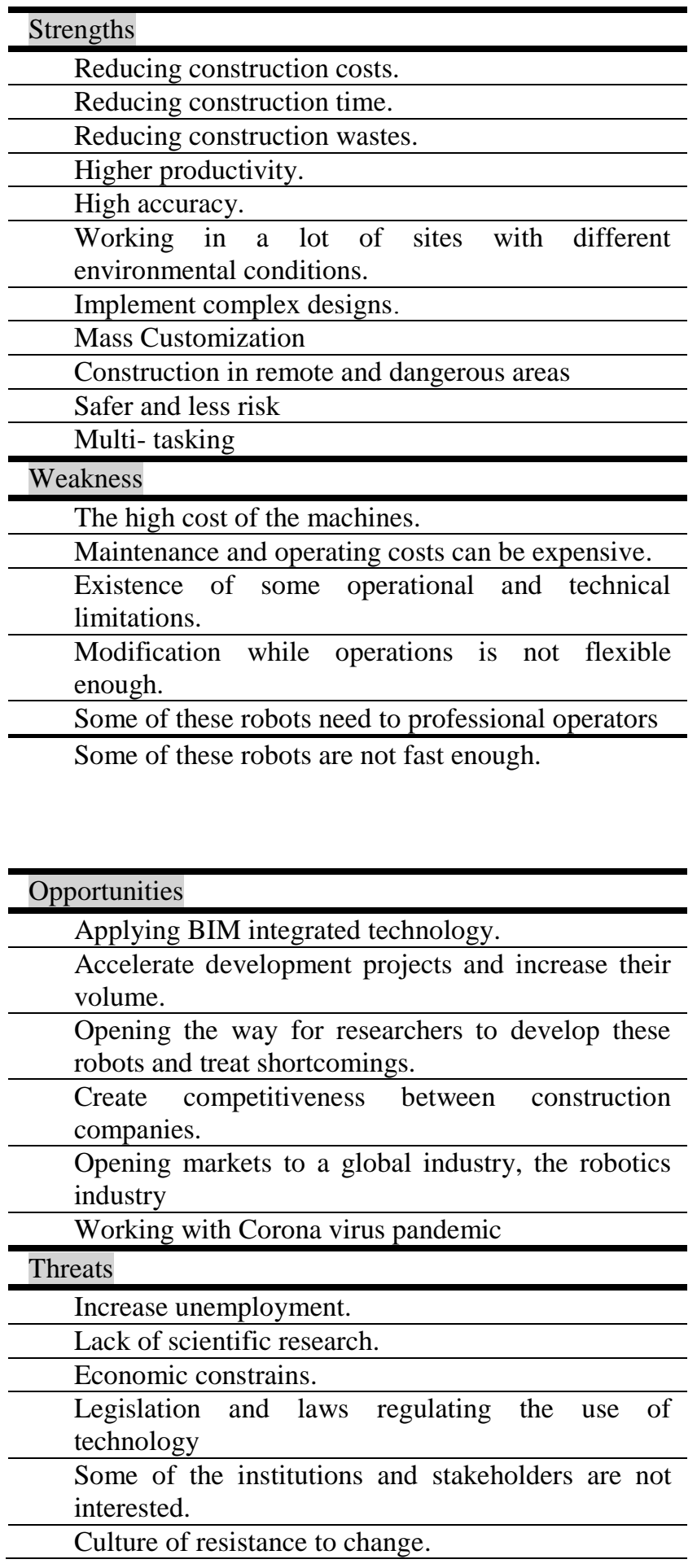

\section{Results and Discussion}

What Egypt is witnessing in the current period of development processes in the construction sector and development and the construction of new cities in a race against time and high efficiency and what the world is witnessing from the Corona virus pandemic may be the motives for using these robots and their technology in the construction development process in Egypt, this will require further study and examination.

Robots may recover the low-quality work among working labour .in addition to save cost and material of construction, increase productivity and decrease Labour injury rates in construction industry.

Ariel robots (drones) provide plenty of time and cost but operate limited distances and are affected by weather conditions and need more training.

Terrestrial robots have high efficiency, save time and cost and are more accurate, they operate in the most difficult work environments and perform multiple tasks, but their initial cost is high.

Under water Robots are not very widespread in construction, but they focus more on monitoring underwater facilities such as dams according to restrictions and limitations.

The results indicate that robots have potentials in its production speed and quality, in addition to reducing wastes, working with high productivity, and more accurate.

Robots have potentials in its production speed and quality which may recover the low-quality work among working labour .in addition to save cost and material of construction, increase productivity and decrease Labour injury rates in construction industry.

The expected challenges to the application of robot's technology are associated with the labour. Especially as construction is one of the largest sectors in Egypt. Official estimates show that the number of informal workers, including craftsmen, daily hire workers and self-employed, is 15 million.[49]

More challenges are related to cost of technology, lack of practical and scientific knowledge, Legislation and laws regulating the use of technology, Lack of interest Some institutions and stakeholders, trained workforce and Culture of resistance to change.

\section{Conclusions}

Although there are some challenges that may hinder the application of robotics technology in the field of construction in Egypt, this technology may be successful in achieving the desired development goals in the construction sectors. It will save time and cost, increase the quality of construction and accelerate the development process. This technology offers alternatives to traditional methods more secure, more productivity, speed and accuracy.

Technology is considered the top solutions to achieving sustainability in the construction industry and addressing deficiencies as a result of unskilled labour, which increases the waste of construction operations and increases the cost of projects. In addition to delays in project schedules and 
stopping due to climatic conditions or health conditions such as Coronavirus pandemic.

These technologies may be reduced energy consumption wasted in transportation operations, which will help Egypt achieve sustainability in the building sector.

\section{References}

[1] E. Gambao and C. Balaguer, Robotics and automation in construction, vol. 9, no. 1. 2002.

[2] S. 2021, "Distribution of GDP in Egypt as of 2019/2020, by sector," https://www.statista.com/, 2021. [Online]. Available: https://www.statista.com/statistics/1203048/gdp-by-sector-inegypt/. [Accessed: 29-Apr-2021].

[3] M. O. A. Gerges, "Investigating and Ranking Labor Productivity Factors in the Egyptian Construction Industry," nternational $J$. Archit. Eng. Constr., vol. 5, pp. 44-52, 2016.

[4] A. R. H., "Factors affecting construction quality in Egypt: identification and relative importance," Eng. Constr. Archit. Manag., vol. 5, no. 3, pp. 220-227, Jan. 1998.

[5] M. S. Mohamed, D. E. Ibrahim, and L. Mohamed Khodeir, "An Evaluation of the Application of Total Quality Management in Construction Projects in Egypt," J. Int. Acad. Res. Multidiscip., vol. 1, no. December, pp. 376-385, 2013.

[6] M. A. El-Razek, H. Bassioni, and A. Mobarak, "Causes of Delay in Building Construction Projects in Egypt," J. Constr. Eng. Manag., vol. 134, pp. 831-841, 2008.

[7] M. M. Marzouk and T. I. El-Rasas, "Analyzing delay causes in Egyptian construction projects," J. Adv. Res., vol. 5, no. 1, pp. 49-55, 2014.

[8] M. Abdel-Wahab, A. Ibrahim, H. Ghatass, and E. Abdel-Galil, "Factors Affecting the Cost of Construction Materials in Egypt," Port-Said Eng. Res. J., vol. 22, pp. 82-89, 2018.

[9] "How the pandemic has (temporarily) cooled growth forecasts for Egypt's construction industry," Enterprise the state of the nation, $2020 . \quad$ [Online]. Available: https://enterprise.press/stories/2020/09/16/how-the-pandemichas-temporarily-cooled-growth-forecasts-for-egyptsconstruction-industry-21982/.

[10] B. Chu, D. Kim, and D. Hong, "Robotic automation technologies in construction: A review," Int. J. Precis. Eng. Manuf., vol. 9, pp. 85-91, Jul. 2008.

[11] B. Robert, "What are the prospects for robots in the construction industry?," Ind. Robot An Int. J., vol. 45, no. 1, pp. 1-6, Jan. 2018.

[12] M. Ben-Ari and F. Mondada, Elements of Robotics (Robots and Their Applications). 2017.

[13] "Robots and robotic devices - Vocabulary," Organisation internatinal de normalisation, 2019. [Online]. Available: https://www.iso.org/obp/ui/\#iso:std:iso:8373:ed-2:v1:en.

[14] M. Ben-Ari and F. Mondada, "Robots and Their Applications BT - Elements of Robotics," M. Ben-Ari and F. Mondada, Eds. Cham: Springer International Publishing, 2018, pp. 1-20.

[15] Robotpark, "All Types Of Robots - By Locomotion," 2016. [Online]. Available: http://www.robotpark.com/All-Types-OfRobots.

[16] F. Liew, D. DeLatte, N. Takeishi, and T. Yairi, Recent Developments in Aerial Robotics: A Survey and Prototypes Overview. 2017.

[17] Bimplus, "UK construction adopts drones faster than any other sector," 2016.2 [Online]. Available: https://www.bimplus.co.uk/news/uk-constru1ction-adopt4ingdrones-fast3er/. [Accessed: 11-Feb-2021].

[18] P. Liu et al., "A review of rotorcraft unmanned aerial vehicle (UAV) developments and applications in civil engineering," Smart Struct. Syst., vol. 13, no. 6, pp. 1065-1094, 2014.

[19] M. Ball, "New Commercial Drone Solution Developed for Industry," unmannedsystemstechnology, 2017. [Online]. Available: https://www.unmannedsystemstechnology.com/2017/06/identifi ed-technologies-dji-develop-new-commercial-drone-solution/.

[20] I. Technologies, No More Late, Over-Budget Projects - Drone Webinar. 2017.

[21] F. Ahmed, M. Amir, and N. Anwar, "Construction monitoring and reporting using drones and unmanned aerial vehicles ( UAVs )," Tenth Int. Conf. Constr. 21st Century, no. July, pp. 18, 2018.

[22] J. Fan and M. A. Saadeghvaziri, "Applications of Drones in Infrastructures: Challenges and Opportunities," World Acad. Sci. Eng. Technol. Int. J. Mech. Mechatronics Eng. Vol13, No10, vol. 13, no. 10, pp. 649-655, 2019.

[23] N. china TV, Asia's longest! Chinese engineers use drone in building mega bridge. 2018.

[24] T. Y. F. MAILONLINE, "Workers use a DRONE to lay cables during construction of $£ 120 \mathrm{~m}$ bridge over raging river," dailymail, 2017. [Online]. Available: https://www.dailymail.co.uk/news/article-4387492/China-usesdrone-build-120mn-bridge.html.

[25] "Husqvarna Construction Products," Mining Technology. [Online]. Available: https://www.miningtechnology.com/contractors/crushers/husqvarna-constructionproducts/\#company-details.

[26] Husqvarnacp, "Demolition robots Husqvarna DXR 310," 2018. [Online]. https://www.husqvarnacp.com/au/machines/demolitionrobots/dxr-310/965995306/.

[27] V. Ciupe and I. Maniu, "New Trends in Service Robotics BT New Trends in Medical and Service Robots: Theory and Integrated Applications," D. Pisla, H. Bleuler, A. Rodic, C. Vaida, and A. Pisla, Eds. Cham: Springer International Publishing, 2014, pp. 57-74.

[28] Husqvarna, "2012 Husqvarna Construction Products Catalog, U.S. Professional," 2012.

[29] Drilltec, "Remote Controlled Demolition," drilltec, 2014. [Online]. Available: https://www.drilltec.co.uk/news/remotecontrolled-demolition/.

[30] M. Jones, "Users Background and Perception of Robotic Demolition Equipment," 2020.

[31] A. J. Madsen, "The SAM100: Analyzing Labor Productivity," 2019.

[32] C. Robotics, SAM100 OS 2.0. 2017.

[33] MEP, "Robotic Solutions," mepgroup, 2018. [Online]. Available:

https://www.mepgroup.com/en/stirrups/machine/aron.

[34] M. G.-M. S. p. . M. E. Piegatrici, ARON - Daehan Networks $x$ MEP. 2018.

[35] “T-iROBO Rebar," Chiba Institute of Technology, 2017. [Online]. Available: https://www.furo.org/en/works/t_irobo_rebar/t_irobo_rebar.html

[36] C. C. I. of Technology, "Developed autonomous rebar binding robot 'T-iROBO Rebar," Taisei, 2017. [Online]. Available: https://www.taisei.co.jp/about_us/wn/2017/171017_3490.html.

[37] S. Jari Komsi, "CONSTRUCTION ROBOTICS, PRESENT IMPLEMENTATION AND PROSPECTS Title Construction robotics, present implementation and prospects," 2019.

[38] Okibo, Okibo - wall plastering robot demonstration. 2019.

[39] "okibo." [Online]. Available: https://okibo.com/our-robot/. [Accessed: 28-Jan-2021].

[40] "Development of a Humanoid Robot Prototype, HRP-5P, Capable of Heavy Labor." [Online]. Available: https://www.aist.go.jp/aist_e/list/latest_research/2018/20181116/ en20181116.html. [Accessed: 22-Jan-2021].

[41] O. Hovland Rosenlund and K. Anfinnsen, "Mobile Drilling Robot A Case Study Of The Effects On The Construction Site," no. June, 2017.

[42] S. Zhang, "Robotic Worker in Construction Industry," Adv. Robot. Mech. Eng., vol. 2, no. 5, pp. 212-216, 2020.

[43] I. Hager, A. Golonka, and R. Putanowicz, "3D Printing of Buildings and Building Components as the Future of Sustainable Construction?," Procedia Eng., vol. 151, no. August, pp. 292$299,2016$. 
[44] D. Delgado Camacho et al., "Applications of additive manufacturing in the construction industry - A forward-looking review," Autom. Constr., vol. 89, no. Isarc, pp. 110-119, 2018.

[45] M. Sakin and Y. C. Kiroglu, "3D Printing of Buildings: Construction of the Sustainable Houses of the Future by BIM," Energy Procedia, vol. 134, pp. 702-711, 2017.

[46] "Deep Trekker Inc." [Online]. Available: https://ca.linkedin.com/company/deep-trekker-inc-. [Accessed: 24-Mar-2021].

[47] "Hydroelectric ROV inspections Deep Trekker robotic solutions," DEEP TREKKER, 2019. [Online]. Available: https://www.deeptrekker.com/news/hydroelectric-rovinspections. [Accessed: 24-Mar-2021].

[48] "DTG3 NAVIGATOR," DEEP TREKKER. [Online]. Available: https://www.deeptrekker.com/shop/products/dtg3-navigator. [Accessed: 24-Mar-2021].

[49] E. T. Staff, "Construction sector provides 3.7M jobs: Min.," 2018. [Online]. Available: https://www.egypttoday.com/Article/3/44450/Constructionsector-provides-3-7M-jobs-Min. 